\title{
Distribution of Vibrio parahaemolyticus in Farmed Shrimp Penaeus vannamei, Farm Water and Sediment
}

\author{
Vandita Kohli ${ }^{1}$ (D) Ramasubramanian Vaidhyanathan ${ }^{2}$, Amjad K. Balange ${ }^{1}$ (D), \\ Binaya Bhusan Nayak ${ }^{1}$ (D) and Sanath H. Kumar ${ }^{1 *}$ \\ ${ }^{1} \mathrm{QC}$ Laboratory, Post Harvest Technology, ICAR-Central Institute of Fisheries Education, Versova, \\ Mumbai - 400 061, Maharashtra, India. \\ ${ }^{2}$ ICAR- Indian Agricultural Statistics Research Institute (IASRI), PUSA, New Delhi - 110 012, India.
}

\begin{abstract}
The halophilic marine bacterium Vibrio parahaemolyticus is a zoonotic pathogen associated with wildcaught and farmed shrimp. The bacterium is an important cause of gastroenteritis associated with the consumption of raw or undercooked seafood. In the present study, the prevalence and human pathogenic potential of Vibrio parahaemolyticus in Penaeus vannamei (tissue and hepatopancreas) and the farm environment (water and sediment) was investigated by conventional culture and molecular techniques. The total Vibrio counts of $P$. vannamei ranged from $<1 \mathrm{CFU} / \mathrm{mL}$ in hemolymph to $7.61 \mathrm{log}$ $\mathrm{CFU} / \mathrm{g}$ in the hepatopancreas. The sediment samples consistently showed the counts of 6-7 log CFU/g, while the pond water had Vibrio counts in the range of 2-3 log CFU/ml. Of 120 Vibrio isolates identified, 87 were confirmed as $V$. parahaemolyticus based on the tox $R$ and $t / h$ gene-specific PCR. The virulence marker gene $t d h$ was not detected in any of the isolates, while the trh gene was detected in $3(3.6 \%)$ isolates. Although the incidence of pathogenic $V$. parahaemolyticus in farmed $P$. vannamei is low, the high numbers of total vibrios and $V$. parahaemolyticus demand constant monitoring of animals and the farm environment for human pathogenic strains of $V$. parahaemolyticus.
\end{abstract}

Keywords: Vibrio parahaemolyticus, pathogenic, zoonotic, shrimp, virulence

*Correspondence: sanathkumar@cife.edu.in; +91 2226361446

(Received: June 15, 2021; accepted: August 11, 2021)

Citation: Kohli V, Vaidhyanathan R, Balange AK, Nayak BB, Kumar SH. Distribution of Vibrio Parahaemolyticus in Farmed Shrimp Penaeus vannamei, Farm Water and Sediment. J Pure Appl Microbiol. 2021;15(3):1608-1616. doi: 10.22207/JPAM.15.3.57

C The Author(s) 2021. Open Access. This article is distributed under the terms of the Creative Commons Attribution 4.0 International License which permits unrestricted use, sharing, distribution, and reproduction in any medium, provided you give appropriate credit to the original author(s) and the source, provide a link to the Creative Commons license, and indicate if changes were made. 


\section{INTRODUCTION}

Among various pathogenic vibrios, Vibrio parahaemolyticus is frequently associated with seafood-borne human gastroenteritis ${ }^{1}$. Consumption of raw or undercooked shellfish is generally responsible for human infections by $V$. parahaemolyticus. However, all strains of $V$. parahaemolyticus are not pathogenic. The strains that produce a thermostable direct hemolysin (TDH) or a TDH-related hemolysin (TRH) are considered pathogenic to humans ${ }^{2}$. The TDHproducing $V$. parahaemolyticus, which comprises less than $1 \%$ of the strains of $V$. parahaemolyticus, is more frequently involved in human infections. Isolates producing TRH alone were first reported to be involved in the outbreak of human gastroenteritis from a patient in the Republic of Maldives ${ }^{3}$. Studies have shown that TRH-positive isolates are more abundant, sometimes as high as $15 \%$ of the total $V$. parahaemolyticus, and usually cause gastrointestinal infections which are less severe in nature ${ }^{4,5}$. Nevertheless, both TDH- and TRH-positive V. parahaemolyticus are considered human pathogens ${ }^{5}$. Infections with $V$. parahaemolyticus usually occur during warm summer months in temperate countries. However, in tropical coastal waters with a more or less stable temperature throughout the year, $V$. parahaemolyticus numbers in seafood are temperature independent but are influenced by fluctuations in salinity ${ }^{6}$. Infections generally occur when seafood containing $10^{7}-10^{8} \mathrm{CFU} /$ $\mathrm{ml} V$. parahaemolyticus is consumed ${ }^{7}$. Several studies have reported the occurrence of TDHand TRH-positive $V$. parahaemolyticus from seafood in India ${ }^{6,8-12}$. Apart from gastroenteritis, $V$. parahaemolyticus can cause wound infections ${ }^{13}$. $V$. parahaemolyticus is also a pathogen of fish and shellfish, and has been associated with disease in milkfish (Chanos chanos) in the Philippines ${ }^{14}$, farmed sea bass (Dicentrarchus labrax) in Tunisia ${ }^{15}$, red disease in Penaeus monodon in India ${ }^{16}$. The significance of $V$. parahaemolyticus as a serious pathogen of farmed shrimp was realized with the establishment of its association with the acute hepatopancreatic necrosis disease AHPND in shrimp ${ }^{17,18}$. With the association of $V$. parahaemolyticus with diseases in farmed fish and shrimp, the bacterium has been recognized as a zoonotic human pathogen. Considering the human health threat this bacterium poses, it is important to routinely monitor the prevalence of $V$. parahaemolyticus in farmed shrimp as part of risk assessment studies. In this context, the study was designed to understand the prevalence of total and human pathogenic $V$. parahaemolyticus in shrimp farm environments on the West Coast in India.

\section{MATERIALS AND METHODS}

\section{Sample collection and preparation}

Twenty-one samples comprising of shrimp (9), water (6), and sediment (6) analyzed in this study were collected from three shrimp $(P$. vannamei) aquaculture farms in Saphale (19.5708 $\left.\mathrm{N}, 72.8309^{\circ} \mathrm{E}\right)$ and Dahanu $\left(19.9903^{\circ} \mathrm{N}, 72.7397^{\circ}\right.$ E) in Palghar district of Maharashtra, India. Fresh shrimp samples were collected directly from the ponds in sampling bags and immediately transported to the laboratory in chilled condition. The water and sediment samples of the ponds were collected from three different locations within a pond and pooled. The total Vibrio counts of shrimp hemolymph, tissue, hepatopancreas, as well as water and sediment samples of the respective ponds were analyzed following standard methods ${ }^{19}$, with some modifications. The samples were surface plated directly on selective agar plates for the quantification of presumptive $V$. parahaemolyticus without the selective enrichment. The salinity and water temperature were measured before the collection of samples. Shrimp samples

Different parts of the shrimp i.e., hepatopancreas, tissue, and hemolymph were processed for the isolation and quantification of $V$. parahaemolyticus. The hemolymph was collected from three live animals from a single pond using sterile syringes and pooled. From this, $0.1 \mathrm{~mL}$ was directly surface plated on thiosulphate citrate bile salt sucrose (TCBS) agar. Tissue and hepatopancreas were sampled from three different shrimps from the same pond and pooled and one gram of the pooled sample was processed further. Briefly, one gram of the hepatopancreas or the tissue was homogenized in $9 \mathrm{~mL}$ of sterile saline solution $(2 \% \mathrm{NaCl} \mathrm{w} / \mathrm{v})$, serially 10 -fold diluted in saline, and $0.1 \mathrm{~mL}$ of the dilutions was spread plated on TCBS agar plates in duplicate. Water and sediment samples 
In the case of water samples, $0.1 \mathrm{~mL}$ was spread plated directly on TCBS agar plates. The sediment sample $(10 \mathrm{~g})$ was mixed with $90 \mathrm{ml}$ of $2 \%(\mathrm{w} / \mathrm{v})$ saline, vortexed for $2 \mathrm{~min}$, and allowed to settle for $5 \mathrm{~min}$. The supernatant was 10 -fold serially diluted in $2 \%$ saline and $0.1 \mathrm{~mL}$ from each dilution was spread plated on TCBS agar plates ${ }^{20}$.

The inoculated plates were incubated at $35^{\circ} \mathrm{C}$ for $18-24 \mathrm{~h}$. Green colonies typical of $V$. parahaemolyticus, 3-5 from each TCBS plate, were picked and streaked on Luria Bertani agar plates containing $2 \% \mathrm{NaCl}$ and incubated for 24 $\mathrm{h}$ at $35^{\circ} \mathrm{C}$. The bacterial isolates were subjected to presumptive identification of Vibrio spp. using biochemical reactions such as the production of cytochrome oxidase, catalase, resistance to 10 $\mu \mathrm{g}$ concentration of the vibriostatic agent $0 / 129$ (2,4-diamino-6,7-diisopropyl pteridine), growth at different concentrations of salt $(0,3,6,8$ and $11 \%$ $\mathrm{w} / \mathrm{v} \mathrm{NaCl}$ ) and glucose fermentation tests.

\section{Molecular characterization}

Vibrio isolates from the samples were subjected to $V$. parahaemolyticus species-specific PCR targeting the tox $R$ and $t / h$ genes. To detect pathogenic strains of $V$. parahaemolyticus, the isolates were subjected to PCR specific for the thermostable direct hemolysin gene $(t d h)$ and the TDH-related hemolysin gene (trh) (Table 1). For preparation of DNA for PCR, a single bacterial colony was suspended in $200 \mu \mathrm{l} 1 \times \mathrm{TE}$ (10 mM Tris pH 8.0; $1 \mathrm{mM}$ EDTA) buffer in a $1.5 \mathrm{~mL}$ microcentrifuge tube and vortexed. The bacterial suspension was lysed by placing the tube in a dry bath at $98^{\circ} \mathrm{C}$ for $10 \mathrm{~min}$, followed by placing it on ice for 5 minutes. The lysate was centrifuged at $10,000 \mathrm{rpm}$ for $2 \mathrm{~min}$ and the resultant supernatant was used as the DNA template in PCR. PCR was performed in $30 \mu \mathrm{l}$ reaction volumes consisting of $3 \mu \mathrm{l}$ of $10 \mathrm{X}$ buffer (DSS Takara Bio India Pvt. Ltd.), $200 \mu \mathrm{M}$ concentrations of each of the four dNTPs, 10 pico moles of each of forward and reverse primers, and $1 \mathrm{U}$ of Taq DNA polymerase (DSS Takara Bio India Pvt. Ltd.) and $3 \mu \mathrm{l}$ of template DNA. The amplifications were performed in SimpliAmp ${ }^{\text {TM }}$ thermal cycler (Thermo Fisher Scientific, USA). V. parahaemolyticus AQ $4037\left(t r h^{+}\right)$and SY 03:K6 $\left(t d h^{+}\right)$were used as the positive controls, while sterile distilled water was used as the negative control. The thermocycling conditions for the amplification of target genes (toxR, $t / h, t r h$ and $t d h$ ) were essentially the same as previously described ${ }^{21,22}$. The PCR amplicons obtained were resolved on $1.5 \%$ agarose gels by electrophoresis. The ethidium bromide-stained gels were then visualized and photographed using a gel documentation system (UVP, CA, USA).

\section{RESULTS AND DISCUSSION \\ Isolation and characterization of V. parahaemolyticus}

The presence of pathogenic and nonpathogenic strains of $V$. parahaemolyticus has been reported from wild-caught seafood in India ${ }^{23-25}$. Although $V$. parahaemolyticus has been considered as an important human pathogen, the bacterium is also an important shrimp pathogen. Studies have reported $V$. parahaemolyticus infections of $P$. monodon and $P$. vannamei at various life stages, from post-larvae to adult shrimps ${ }^{26,27}$. The zoonotic potential of $V$. parahaemolyticus makes it an important pathogen of public health significance as well. V. parahaemolyticus in shrimp

Table 1. Oligonucleotide primers used in the study

\begin{tabular}{|c|c|c|c|}
\hline $\begin{array}{l}\text { Target } \\
\text { gene }\end{array}$ & Primer sequence $\left(5^{\prime}-3^{\prime}\right)$ & $\begin{array}{l}\text { Amplicon } \\
\text { size (bp) }\end{array}$ & Reference \\
\hline \multirow[t]{2}{*}{ tox $R$} & F: GTC TTC TGA CGC AAT CGT TG & 368 & 21 \\
\hline & R: ATA CGA GTG GTT GCT GTC ATG & & \\
\hline \multirow[t]{2}{*}{$t d h$} & F: AAA GCG GAT TAT GCA GAA GCA CTG & 269 & \\
\hline & R: GCT ACT TTC TAG CAT TTT CTC TGC & & \\
\hline \multirow[t]{2}{*}{ trh } & F: GTA AAG GTC TCT GAC TTT TGG AC & & \\
\hline & R: TGG AAT AGA ACC TTC ATC TTC ACC & 500 & 22 \\
\hline \multirow[t]{2}{*}{ t/h } & F: TTG GCT TCG ATA TTT TCA GTA TCT & & \\
\hline & R: CAT AAC AAA CAT ATG CCC ATT TCC G & 450 & \\
\hline
\end{tabular}


farm environment can lead to persistent infections and crop losses ${ }^{28,29}$, while its presence in processed shrimp can lead to consignment rejections ${ }^{30}$. In this context, it is important to monitor farmed shrimp for the presence of $V$. parahaemolyticus in general and human pathogenic ( $t d h$ - and/trh-positive) $V$. parahaemolyticus in particular.

Twenty-one samples collected from three different shrimp farms were analyzed for the presence of $V$. parahaemolyticus. A total of 120 isolates, identified as Vibrio spp. by biochemical tests, were recovered from the samples. Of these, 31 isolates were from shrimp tissue, 59 were from shrimp hepatopancreas, and 15 each were from water and sediment samples (Table 2). These isolates were subjected to $V$. parahaemolyticusspecific PCR targeting tox $R$ and th genes. Of 120 isolates, $87(72.5 \%)$ isolates were confirmed as V. parahaemolyticus by PCR (Fig. 1A \& 1B). The difference in the nucleotide sequences of toxR gene among different Vibrio spp. has been utilized to develop species-specific primers ${ }^{21}$. The toxR specific PCR has been used by several investigators to identify $V$. parahaemolyticus isolated from seafood ${ }^{6,31,32}$. The prevalence studies of $V$. parahaemolyticus from India reported $89 \%$ in seafood in general ${ }^{33}$ and $80 \%$ in shrimps ${ }^{34}$.

Studies on farmed shrimp and the

Table 2. Details of the total (and pathogenic Vibrio parahaemolyticus isolated from shrimp, water and sediment samples

\begin{tabular}{lccccc}
\hline Sample Type & $\begin{array}{c}\text { No. of Vibrio } \\
\text { isolates recovered }\end{array}$ & $\begin{array}{c}\text { No. toxR } \\
\text { positive }\end{array}$ & $\begin{array}{c}\text { No.th } \\
\text { positive }\end{array}$ & $\begin{array}{c}\text { No.trh } \\
\text { positive }\end{array}$ & $\begin{array}{c}\text { No. } t d h \\
\text { positive }\end{array}$ \\
\hline Hepatopancreas & 59 & 50 & 50 & 2 & 0 \\
Tissue & 21 & 21 & 21 & 0 & 0 \\
Water & 15 & 7 & 7 & 0 & 0 \\
Sediment & 15 & 9 & 9 & 1 & 0 \\
Total & 120 & 87 & 87 & 3 & 0 \\
\hline
\end{tabular}

$¥$ Based on the biochemical tests

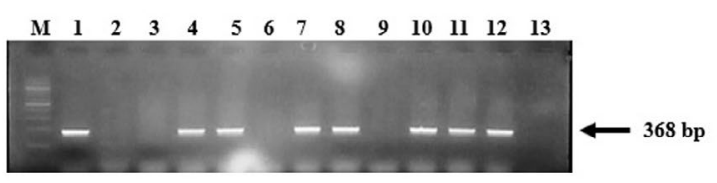

A

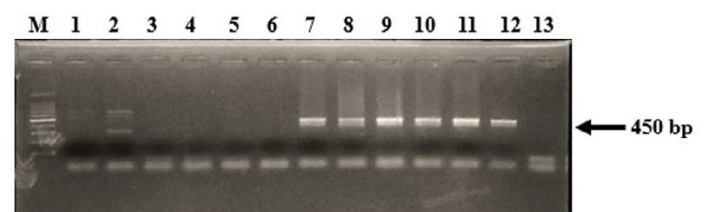

B

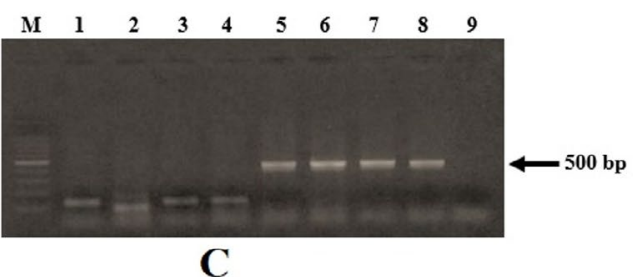

Fig 1. Agarose gel electrophoresis for the vibrio isolates

Detection of toxR gene (A). Lane M: 1 kb DNA ladder (Thermo Fisher Scientific, USA); lanes 1-11: presumptive $V$. parahaemolyticus isolates from shrimp, water and sediment samples; lane 12: positive control (V. parahaemolyticus AQ 4037); lane 13: negative control

Detection of th gene (B). Lane M: 100 bp DNA ladder (Thermo Fisher Scientific, USA); lanes 1-3: isolates from sediment; lanes 4-5: isolates from water; lanes 6-8: isolates from hepatopancreas; lanes 9-11: isolates from shrimp tissue; lane 12: positive control (V. parahaemolyticus AQ 4037); lane 13: negative control.

Detection of trh gene (C). Lane M: 100 bp DNA ladder (Thermo Fisher Scientific, USA); lanes 1-2: isolates from shrimp tissue; lanes 3-4: isolates from water; lanes 5-6: isolates from hepatopancreas; lanes 7: isolates from sediment; lane 8: positive control (V. parahaemolyticus AQ 4037); lane 9: negative control. 
farm environments have reported that the V. parahaemolyticus is commonly associated with shrimps, although their numbers can vary depending on the temperature, salinity, and other abiotic and biotic factors ${ }^{35,36}$. V. parahaemolyticus was reported to be the dominant Vibrio spp. after $V$. harveyi and $V$. splendidus in the hepatopancreas of pond-reared Penaeus monodon juveniles affected with luminous vibriosis ${ }^{37}$. Other studies have reported $V$. parahaemolyticus as the predominant Vibrio spp. in farmed Penaeus monodon $^{38,39}$. Sanathkumar et $\mathrm{al}^{40}$ reported heavy colonization of $L$. vannamei hepatopancreas with $V$. parahaemolyticus. Our results on the distribution of $V$. parahaemolyticus in shrimp aquaculture farms suggest that $V$. parahaemolyticus is commonly associated with farmed $L$. vannamei, farm water, and sediments.

In our study, the Vibrio counts in animal tissues (muscle and hepatopancreas) were in the range of 2-4 log CFU/g, while the counts in the sediment samples were uniformly around 6-7 log CFU/g (Table 3). In shrimp farm water samples, the counts ranged from 2.48-3.59 log CFU/ml. The water temperature and salinity of ponds sampled in this study did not vary significantly throughout the study period of three months. The salinity was in the range of 22-23 ppt, and the temperature was in the range of $27-29^{\circ} \mathrm{C}$ (Table 3). Therefore, salinity and temperature presumably did not influence Vibrio populations of shrimp ponds investigated in this study. In general, the Vibrio counts of the sediment samples were higher than the counts in tissues or the water samples (Table 3 ). The higher surface area of sediment particles and the associated nutrients might support higher bacteria populations in pond sediments compared to water. In our study, the counts from the shrimp sample were higher than counts from the farm environment. Higher Vibrio counts in sediments compared to the water have been reported by other investigators ${ }^{41,42}$. In an elegant study mimicking shrimp farm environment, Zheng et $\mathrm{al}^{43}$ showed significant dissimilarities in microbial composition and diversity of water, sediment, and shrimp intestine. The microbial communities varied during different stages of shrimp culture. However, the changes in shrimp gut microbial communities did not resemble the changes in the surrounding environment ${ }^{43}$. Differences in water, sediment, and shrimp gut Vibrio counts have been reported by several investigators ${ }^{44-46}$. While physicochemical parameters such as temperature, salinity, $\mathrm{pH}$, and nutrients greatly influence Vibrio counts in the shrimp farm water and sediment, additional factors such as the health and immunity of shrimp, diet, pond application of probiotics, etc. determine the gut microbial communities of farmed shrimp ${ }^{46}$.

Molecular characterization of $V$. parahaemolyticus The main goal of this study was to understand the prevalence of human pathogenic $V$. parahaemolyticus in P. vannamei farm environment. The tox $R$ positive isolates were further screened for the virulence genes trh and $\mathrm{tdh}$. None of the isolates harbored the $t d h$ gene, while the trh gene was detected in 2 isolates from shrimp hepatopancreas and 1 isolate from the pond sediment (Fig. $1 \mathrm{C}$ ). These isolates corresponded to two separate samples of shrimp and sediment. Thus, the incidence of $t r h^{+} \mathrm{V}$. parahaemolyticus in this study was $22.2 \%$ of shrimp samples and $16.6 \%$ of sediment samples. The $t d h$ gene, which encodes a thermostable

Table 3. Total Vibrio counts of the samples analyzed from the shrimp farms

\begin{tabular}{|c|c|c|c|c|c|c|c|}
\hline \multirow[t]{2}{*}{ Date } & \multirow{2}{*}{$\begin{array}{l}\text { Salinity } \\
\text { (ppm) }\end{array}$} & \multirow{2}{*}{$\begin{array}{c}\text { Temp. } \\
\left({ }^{\circ} \mathrm{C}\right)\end{array}$} & \multicolumn{3}{|c|}{ Shrimp (log CFU/g or ml) (n=9) } & \multirow{2}{*}{$\begin{array}{c}\text { Sediment } \\
(\log C F U / g) \\
(n=6)\end{array}$} & \multirow{2}{*}{$\begin{array}{c}\text { Water } \\
(\log \text { CFU/ml) } \\
(n=6)\end{array}$} \\
\hline & & & Tissue & Hepatopancreas & Hemolymph & & \\
\hline 11-08-2017 & 23 & 27 & 4.09 & 5.13 & $<1^{*}$ & 6.33 & 2.4 \\
\hline 21-08-2017 & 22 & 28 & 6.1 & 6.39 & $<1$ & 7.08 & 2.28 \\
\hline 11-09-2017 & 23 & 29 & 7.37 & 7.61 & $<1$ & 7.67 & 3.53 \\
\hline 22-09-2017 & 23 & 28 & 6.84 & 7.7 & $<1$ & 7.44 & 3.66 \\
\hline $12-10-2017$ & 22 & 27 & 5.89 & 5.17 & $<1$ & 6.42 & 3.25 \\
\hline $26-10-2017$ & 22 & 28 & 6.22 & 6.35 & $<1$ & 7.48 & 3.47 \\
\hline
\end{tabular}

$\mathrm{n}=$ number of samples; $¥=$ Indicates no viable growth on plates by spread plate method. 
direct hemolysin, is predominantly associated with clinical isolates of $V$. parahaemolyticus and only a small proportion $(<1 \%)$ of the environmental isolates carry this gene ${ }^{5,6,47}$. However, the incidence of trh-positive $V$. parahaemolyticus in wild-caught fish and shellfish is relatively higher than reported in this study. Ayyapan et $\mathrm{al}^{11}$ isolated trh-positive V. parahaemolyticus from $2 \%$ of shellfish, $16 \%$ of coastal water, and $5 \%$ of coastal sediment samples, while Deepanjali et $\mathrm{al}^{6}$ reported that $59 \%$ of oyster samples harbored trh-positive $V$. parahaemolyticus. The reported prevalence of pathogenic $V$. parahaemolyticus in shrimp culture environment is low in India ${ }^{8,29,40}$. However, recently a study from India reported a high prevalence of $t d h$ - and trh-positive $V$. parahaemolyticus in shrimp farms $s^{34}$. No or low prevalence of pathogenic $V$. parahaemolyticus isolated from aquaculture farms has been reported from Mexico ${ }^{48}$ Brazil $^{49}$, Bangladesh $^{36}$, China $^{50}$, and Sri Lanka ${ }^{51}$. A study from Thailand on farmed shrimp reported a relatively higher $\left(15.9 \% t d h^{+}\right.$and $\left.4.6 \% t r h^{+}\right)$ prevalence of pathogenic $V$. parahaemolyticus ${ }^{52}$. In this study, we did not perform selective enrichment of the samples before the isolation of V. parahaemolyticus on TCBS agar. The total Vibrio count in the selective plates was as high as 7 log CFU/g in the hepatopancreas and pond sediment. Despite this high number, the $t d h$-positive $V$. parahaemoloyticus was distinctly absent from the samples. It is worthwhile to compare direct plating with selective enrichment followed by isolation on selective agar, particularly in the case of farmed shrimp where high $V$. parhaemolyticus loads are expected, to determine if enrichment allows better isolation of $t d h^{+} V$. parahaemolyticus

\section{CONCLUSION}

Risk assessment of $V$. parahaemolyticus in farmed shrimp requires continuous monitoring for total and pathogenic strains in the farm environment. The present study suggests that $V$. parahaemolyticus can be commonly found in farmed shrimp, both on the surface as well as in the hepatopancreas. However, V. parahaemolyticus encountered in shrimp farm environments in this study were, by far, non-pathogenic, although a small percentage of strains harbored the trh gene. Since $V$. parahaemolyticus is a known shrimp pathogen, the abundance of this bacterium also depends on the health of the animals and physico-chemical characters of pond water. Pre-harvest testing of shrimp for pathogenic $V$. parahaemolyticus can help in ensuring the safety of seafood and compliance with the regulatory standards of importing countries.

\section{ACKNOWLEDGMENTS}

The authors thank Director, ICAR-CIFE, Mumbai for providing the necessary facilities for carrying out this research.

\section{CONFLICT OF INTEREST}

The authors declare that there is no conflict of interest.

\section{AUTHORS' CONTRIBUTION}

VK performed the bench work and sample analysis. SK and BBN conceptualized the project, supervised the research and analyzed the results. AKB and RV supervised the research and analyzed the results. All authors contributed to manuscript preparation, correction and approved the final version.

\section{FUNDING}

None.

\section{DATA AVAILABILITY}

All datasets generated or analyzed during this study are included in the manuscript.

\section{ETHICS STATEMENT}

This article does not contain any studies with human participants or animals performed by any of the authors.

\section{REFERENCES}

1. Letchumanan V, Chan KG, Lee L-H. Vibrio parahaemolyticus: A review on the pathogenesis, prevalence, and advance molecular identification techniques. Front Microbiol. 2014;5:705. doi: 10.3389/ fmicb.2014.00705

2. Williams TC, Froelich BA, Phippen B, Fowler P, Noble RT, Oliver JD. Different abundance and correlational patterns exist between total and presumed pathogenic Vibrio vulnificus and Vibrio parahaemolyticus in shellfish and waters along the North Carolina coast. FEMS Microbiology Ecology. 2017;93(6):1-11. doi: 10.1093/femsec/fix071

3. Honda T, Ni Y, Miwatani T. Purification and characterization of a hemolysin produced by a clinical isolate of Kanagawa phenomenon-negative Vibrio 
parahaemolyticus and related to the thermostable direct hemolysin. Infect Immun. 1988;56(4):961-965. doi: 10.1128/iai.56.4.961-965.1988

4. Robert-Pillot A, Guenole A, Lesne J, Delesmont R, Fournier JM, Quilici ML. Occurrence of the $t d h$ and trh genes in Vibrio parahaemolyticus isolates from waters and raw shellfish collected in two French coastal areas and from seafood imported into France. Int $J$ Food Microbiol. 2004;91(3):319-325. doi: 10.1016/j. ijfoodmicro.2003.07.006

5. Honda T, lida T. The pathogenicity of Vibrio parahaemolyticus and the role of the thermostable direct haemolysin and related haemolysins. Rev Med Microbiol. 1993;4(2):106-113. doi: 10.1097/00013542199304000-00006

6. Deepanjali A, Kumar HS, Karunasagar I, Karunasagar I. Seasonal variation in abundance of total and pathogenic Vibrio parahaemolyticus bacteria in oysters along the southwest coast of India. Appl Environ Microbiol. 2005;71(7):3575-3580. doi: 10.1128/ AEM.71.7.3575-3580.2005

7. Parthasarathy S, Das SC, Kumar A. Occurrence of pathogenic Vibrio parahaemolyticus in crustacean shellfishes in coastal parts of Eastern India. Vet World. 2016;9(3):330-336. doi: 10.14202/ vetworld.2016.330-336

8. Gopal S, Otta SK, Kumar S, Karunasagar I, Nishibuchi $M$, Karunasagar I. The occurrence of Vibrio species in tropical shrimp culture environments; implications for food safety. Int J Food Microbiol. 2005;102(2):151-159. doi: 10.1016/j.ijfoodmicro.2004.12.011

9. Raghunath $P$, Karunasagar I, Karunasagar I. Improved isolation and detection of pathogenic Vibrio parahaemolyticus from seafood using a new enrichment broth. Int J Food Microbiol. 2009;129(2):200-203. doi: 10.1016/j.ijfoodmicro.2008.11.026

10. Sudha S, Divya PS, Francis B, Hatha AM. Prevalence and distribution of Vibrio parahaemolyticus in finfish from Cochin (south India). Vet Ital. 2012;48(3):269-281. http://www.ncbi.nlm.nih.gov/pubmed/23038073.

11. Ayyappan M V, Balange AK, Nayak BB, Kumar S. Distribution of Potentially Pathogenic Vibrio parahaemolyticus in Seafood and the Aquatic Environment of Mumbai, India. Fish Technol. 2018;55(3):205-211.

12. Narayanan SV, Joseph TC, Peeralil S, Mothadaka MP, Lalitha KV. Prevalence, Virulence Characterization, AMR Pattern and Genetic Relatedness of Vibrio parahaemolyticus Isolates From Retail Seafood of Kerala, India. Front Microbiol. 2020;11:592. doi: 10.3389/fmicb.2020.00592

13. Daniels NA, MacKinnon L, Bishop R, et al. Vibrio parahaemolyticus infections in the United States, 1973-1998. J Infect Dis. 2000;181(5):1661-1666. doi: 10.1086/315459

14. Austin B, Austin DA. Bacterial Fish Pathogens Diseases of Farmed and Wild Fish. $4^{\text {th }}$ Ed. Chichester, UK: Praxis Publishing Ltd.; 2007.

15. Khouadja S, Lamari F, Bakhrouf A. Characterization of Vibrio parahaemolyticus isolated from farmed sea bass (Dicentrarchus labrax) during disease outbreaks. Int Aquat Res. 2013;5(1):13. doi: 10.1186/2008-6970-5-13
16. Jayasree L, Janakiram P, Madhavi R, Characterization of Vibrio spp. associated with diseased shrimp from culture ponds of Andhra Pradesh (India). J World Aquacul Soc. 2006;37(4):523-532. doi: 10.1111/j.17497345.2006.00066.x

17. Tran L, Nunan L, Redman RM, et al. Determination of the infectious nature of the agent of acute hepatopancreatic necrosis syndrome affecting penaeid shrimp. Dis Aquat Org. 2013;105(1):45-55. doi: 10.3354/dao02621

18. Restrepo L, Bayot B, Betancourt I, Pinzon A. Draft genome sequence of pathogenic bacteria Vibrio parahaemolyticus strain Ba94C2, associated with acute hepatopancreatic necrosis disease isolate from South America. Genomics Data. 2016;9:143-144. doi: 10.1016/j.gdata.2016.08.008

19. Kaysner CA, Angelo DePaola J. BAM: Vibrio. U.S. Food Drug Administration. https://www.fda.gov/food/ laboratory-methods-food/bam-vibrio. Published 2004. Accessed February 3, 2020.

20. Lekshmy S, Nansimole A, Mohandas M, Athithan N, Radhakrishnan T. Occurrence of Vibrio cholerae in shrimp culture environments of Kerala, India. Indian J Sci Res Technol. 2014;5(2):151-160.

21. Kim YB, Okuda J, Matsumoto C, Takahasi N, Hashimoto S, Nishibuichi M. Identification of Vibrio parahaemolyticus strains at species level by PCR targeted to toxR gene. J Clin Microbiol. 1999;37(4):1173-1177. doi: 10.1128/JCM.37.4.11731177.1999

22. Bej AK, Patterson DP, Brasher CW, Vickery $\mathrm{MCL}$, Jones DD, Kaysner CA. Detection of total and hemolysinproducing Vibrio parahaemolyticus in shellfish using multiplex PCR amplification of $t l, t d h$ and $t r h . J$ Microbiol Methods. 1999;36(3):215-225. doi: 10.1016/ S0167-7012(99)00037-8

23. Lopatek M, Wieczorek K, Osek J. Antimicrobial resistance, virulence factors, and genetic profiles of Vibrio parahaemolyticus from seafood. Appl Environ Microbiol. 2018;84(16):1-10. doi: 10.1128/ AEM.000537-18

24. Rosec JP, Simon M, Causse V, Boudjemaa M. Detection of total and pathogenic Vibrio parahaemolyticus in shellfish: Comparison of PCR protocols using $\mathrm{pR72H}$ or toxR targets with a culture method. Int J Food Microbiol. 2009;129(2):136-145. doi: 10.1016/j. ijfoodmicro.2008.11.017

25. Yang Y, Xie J, Li H, Tan S, Chen Y, Yu H. Prevalence, antibiotic susceptibility and diversity of Vibrio parahaemolyticus isolates in seafood from South China. Front Microbiol. 2017;8:2566. doi: 10.3389/ fmicb.2017.02566

26. Raja AR, Sridhar R, Balachandran C, Palanisammi A, Ramesh S, Nagarajan K. Pathogenicity profile of Vibrio parahaemolyticus in farmed Pacific white shrimp, Penaeus vannamei. Fish Shellfish Immunol. 2017;67:368-381. doi: 10.1016/j.fsi.2017.06.020

27. Soto-Rodriguez SA, Gomez-Gil B, Lozano-Olvera R, Betancourt-Lozano M, Morales-Covarrubias MS. Field and experimental evidence of Vibrio parahaemolyticus as the causative agent of acute hepatopancreatic necrosis disease of cultured shrimp (Litopenaeus 
vannamei) in Northwestern Mexico. Appl Environ Microbiol. 2015; 81(5):1689-1699. doi: 10.1128/ AEM.03610-14.

28. Chonsin K, Matsuda S, Theethakaew C, et al. Genetic diversity of Vibrio parahaemolyticus strains isolated from farmed Pacific white shrimp and ambient pond water affected by acute hepatopancreatic necrosis disease outbreak in Thailand. FEMS Microbiol Lett. 2016;363(2):fnv222. doi: 10.1093/femsle/fnv222

29. Navaneeth KA, Bhuvaneswari T, Rajan JJS, Alavandi SV, Vijayan KK, Otta SK. Characterization of Vibrio parahaemolyticus isolates from shrimp farms of Southeast coast of India with special reference to Acute Hepatopancreatic Necrosis Disease (AHPND) status. Aquaculture. 2020;518:734813. doi: 10.1016/j. aquaculture.2019.734813

30. Geetha R, Ravisankar T, Patil PK, et al. Trends, causes, and indices of import rejections in international shrimp trade with special reference to India: a 15-year longitudinal analysis. Aquacult Int. 2020;28(2):13411369. doi: 10.1007/s10499-020-00529-w

31. Dileep V, Kumar HS, Kumar Y, Nishibuchi M, Karunasagar I, Karunasagar I. Application of polymerase chain reaction for detection of Vibrio parahaemolyticus associated with tropical seafoods and coastal environment. Lett App/ Microbiol. 2003;36(6):423-427. doi: 10.1046/j.1472-765X.2003.01333.x

32. Saito $S$, Iwade $Y$, Tokuoka E, et al. Epidemiological evidence of lesser role of thermostable direct hemolysin (TDH) - Related hemolysin (TRH) than TDH on Vibrio parahaemolyticus pathogenicity. Foodborne Pathog Dis. 2015;12(2):131-138. doi: 10.1089/ fpd.2014.1810

33. Sujeewa AKW, Norrakiah AS, Laina M. Prevalence of toxic genes of Vibrio parahaemolyticus in shrimps (Penaeus monodon) and culture environment. Int Food Res J. 2009;16(1):89-95.

34. Narayanan SV, Joseph TC, Peeralil S, et al. Tropical shrimp aquaculture farms harbour pathogenic Vibrio parahaemolyticus with high genetic diversity and Carbapenam resistance. Mar Pollut Bull. 2020;160:111551. doi: 10.1016/j. marpolbul.2020.111551

35. Alagappan KM, Deivasigamani B, Somasundaram ST, Kumaran S. Occurrence of Vibrio parahaemolyticus and its specific phages from shrimp ponds in east coast of India. Curr Microbiol. 2010;61(4):235-240. doi: 10.1007/s00284-010-9599-0

36. Siddique $A B$, Moniruzzaman $M$, Ali $S$, et al. Characterization of pathogenic Vibrio parahaemolyticus isolated from fish aquaculture of the Southwest Coastal Area of Bangladesh. Front Microbiol. 2021;12:635539. doi: 10.3389/fmicb.2021.635539.

37. Leano EM, Lavilla-Pitogo CR, Paner MG. Bacterial flora in the hepatopancreas of pond-reared Penaeus monodon juveniles with luminous vibriosis. Aquaculture. 1998;164:367-374. doi: 10.1016/S00448486(98)00201-4

38. Babu B, Sathiyaraj G, Mandal A, et al. Surveillance of disease incidence in shrimp farms located in the east coastal region of India and in vitro antibacterial efficacy of probiotics against Vibrio parahaemolyticus.
J Invertebr Pathol. 2021;179:107536. doi: 10.1016/j. jip.2021.107536

39. Sperling L, Alter T, Huehn S. Prevalence and antimicrobial resistance of Vibrio spp. in retail and farm shrimps in Ecuador. J Food Prot. 2015;78(11):20892092. doi: 10.4315/0362-028X.JFP-15-160

40. Sanathkumar H, Ravi C, Padinhatupurayil SB, Mol M, Prasad JK, Nayak BB. Microbiological investigation of persistent mortalities in Litopenaeus vannamei grown in low saline waters in India. J Aquat Anim Health. 2014;26(3):154-159. doi: 10.1080/08997659.2014.902875

41. Devi R, Surendran PK, Chakraborty K. Antibiotic resistance and plasmid profiling of Vibrio parahaemolyticus isolated from shrimp farms along the Southwest coast of India. World I Microbiol Biotechnol. 2009;25(11):2005-2012. doi: 10.1007/ s11274-009-0101-8

42. Anand TP, Edward JKP, Ayyakkannu K. Monitoring of a shrimp culture system with special reference to Vibrio and fungi. Indian J Geo-Marine Sci. 1996;25:253-258.

43. Zeng $S$, Khoruamkid $S$, Kongpakdee $W$, et al. Dissimilarity of microbial diversity of pond water, shrimp intestine and sediment in Aquamimicry system. AMB Express. 2020;10:180. doi: 10.1186/s13568-02001119-y

44. Johnson CN, Barnes S, Ogle J, et al. Microbial community analysis of water, foregut, and hindgut during growth of pacific white shrimp, Litopenaeus vannamei, in closed-system aquaculture. J World Aquac Soc. 2008;39(2):251-258. doi: 10.1111/j.17497345.2008.00155.x

45. Md Zoqratt MZH, Eng WWH, Thai BT, Austin CM, Gan HM. Microbiome analysis of Pacific white shrimp gut and rearing water from Malaysia and Vietnam: implications for aquaculture research and management. Peer J. 2018;6:e5826. doi: 10.7717/ peerj.5826

46. Le DH, Nguyen NT, Dang OHT, et al. Characterization of bacterial community in the gut of Penaeus monodon and its culture water in shrimp ponds. Turkish J Fish Aquat Sci. 2019;19(11):977-986. doi: 10.4194/13032712-v19_11_09

47. Shirai $\mathrm{H}$, Ito $\mathrm{H}$, Hirayama T, et al. Molecular epidemiologic evidence for association of thermostable direct hemolysin (TDH) and TDH-related hemolysin of Vibrio parahaemolyticus with gastroenteritis. Infect Immun. 1990;58(11):3568-3573. doi: 10.1128/iai.58.11.35683573.1990

48. Gámez-Bayardo S, Castañeda-Ruelas GM, EspinosaPlascencia A, Bermúdez-Almada MC, Jiménez-Edeza M. Characterization of Vibrio parahaemolyticus strains and evaluation of shrimp cultivation conditions in a farm at the northwestern of Mexico, as risk predictors for its adaptation and dissemination. Lat Am J Aquat Res. 2021;49(1):75-85. doi: 10.3856/vol49-issue1fulltext-2512

49. De Melo LMR, Almeida D, Hofer E, et al. Antibiotic resistance of Vibrio parahaemolyticus isolated from pond-reared Litopenaeus vannamei marketed in Natal, Brazil. Brazilian J Microbiol. 2011;42(4):1463-1469. doi: 10.1590/S1517-83822011000400032 
50. Xie ZY, Hu CQ, Chen C, Zhang LP, Ren CH. Investigation of seven Vibrio virulence genes among Vibrio alginolyticus and Vibrio parahaemolyticus strains from the coastal mariculture systems in Guangdong, China. Lett Appl Microbiol. 2005;41(2):202-207. doi: 10.1111/j.1472-765X.2005.01688.x

51. Koralage MSG, Alter T, Duangporn P, Strauch E, Zessin $K$, Huehn S. Prevalence and Molecular Characteristics of Vibrio spp. Isolated from Preharvest Shrimp of the North Western Province of Sri Lanka. J Food Prot. 2012;75(10):1846-1850. doi: 10.4315/0362-028x.jpp12-115

52. Yingkajorn $\mathrm{M}$, Mitraparp-Arthorn $\mathrm{P}$, Nuanualsuwan $S$, et al. Prevalence and quantification of pathogenic Vibrio parahaemolyticus during shrimp culture in Thailand. Dis Aquat Organ. 2014;112(2):103-111. doi: 10.3354/dao02800 